\section{EDUCATION}

Research, Innovation and Solutions on-line ${ }^{(2)}$
Electronic Journal of Research

in Educational Psychology

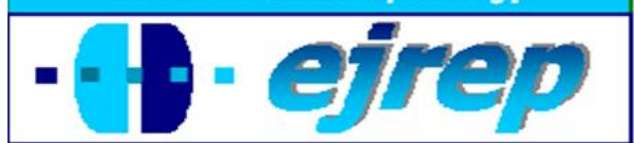

\title{
Critical Thinking Motivational Scale: a contri- bution to the study of relationship between critical thinking and motivation
}

\section{Jorge Valenzuela ${ }^{1}$, Ana $\mathrm{M}^{\mathrm{a}}$ Nieto $^{2}$, Carlos Saiz ${ }^{2}$}

${ }^{1}$ Facultad de Educación, Universidad Católica de Temuco.

${ }^{2}$ Facultad de Psicología, Universidad de Salamanca.

\section{Chile / Spain}

Correspondencia: Jorge Valenzuela. Facultad de Educación, Manuel Montt 56, Edificio A, 3er Piso. Temuco, Chile. E-mail: jorge.valenzuela@uct.cl

(c) Education \& Psychology I+D+i and Editorial EOS (Spain) 


\begin{abstract}
Introduction. The present work reports the characteristics of an instrument measuring the degree of motivation that people possess to think critically. The Critical Thinking Motivation Scales $(C T M S)$ is based on a theoretical option that affords precedence to the perspective of motivation for over the perspective of dispositions. Motivation is understood as the expectancy/value. This sound theoretical frame offers further possibilities for researching factors that affect the activation of cognitive resources for the acquisition and deployment of critical thinking.
\end{abstract}

Method. In this study 470 university students enrolled in Psychology degree programs were evaluated with CTMS. Factorial structure, reliability, and discriminatory capacity of this test were analysed. Also it was calculated the correlations between the CTMS and a critical thinking test: CT_MSLQ.

Results. The results reveal that the CTMS has factorial structure compatible with Eccles and Wigfield motivation model, good realiability levels and discriminatory capacity and significative correlation with CT-MSLQ.

Discussion and Conclusion. This study shows that the CTMS has psychometric characteristics that endorse it as a valid and reliable test. It is also a tool for the study of the motivational factors of critical thinking that may be useful in pedagogic instruction and intervention.

Keywords: Critical thinking; motivation; dispositions; expectancy; value; test, psychometrics characteristics.

Received: 04/28/11 Initial acceptance: 05/16/11 Final acceptance: 07/18/11 


\section{Critical Thinking Motivational Scale (CTMS): una apor- tación para el estudio de la relación entre el pensamiento crítico y la motivación}

\section{Resumen}

Introducción. El presente artículo presenta las características de un instrumento que permite evaluar el grado de motivación, que las personas tienen con respecto a pensar de manera crítica. La Escala Motivacional de Pensamiento Crítico (EMPC) se sustenta en una opción teórica que destaca la perspectiva de la motivación por sobre la perspectiva de las disposiciones. La motivación es entendida a partir del modelo Expectancy / value. Este sólido marco teórico ofrece más posibilidades para la investigación de los factores que inciden en la activación de recursos cognitivos para el aprendizaje y desempeño del pensamiento crítico.

Método. En este estudio participaron 470 universitarios españoles quienes fueron evaluados con la EMPC. Se analizaron la estructura factorial, confiabilidad y capacidad de discriminación de la prueba. Asímismo, se correlacionó esta prueba con una medidad de Pensamiento Crítico: CT_MSLQ.

Resultados. Los resultados revelan que la EMPC tiene una estructura factorial compatible con el modelo motivacional de Eccles y Wigfield, altos indices de confiabilidad y una adecuada capacidad de discriminación. Asimismo se observa una correlación siginificativa con el CT-MSLQ.

Discusión y Conclusión: Los resultados muestran que la EMPC posee características psicométricas que lo avalan como una prueba válida y fiable. Se aporta así una herramienta para el estudio de los factores motivacionales del pensamiento crítico el cual puede ser especialmente útil en la perspectiva de la instrucción y la intervención pedagógica.

Palabras Clave: Pensamiento Crítico; Motivación; disposiciones; Expectativas; valor; test; características psicométricas 


\section{Introduction}

\section{Critical thinking}

Critical thinking is reasoned, reflective thinking focused on deciding what to believe or what to do (Ennis, 1996). People think critically when they are trying to solve a problem, assess an argument, decide about a belief, or make a decision in general. To achieve these ends, critical thinking assesses not only the products and results of thought -that is, beliefs, choices, conclusions, hypotheses, etc., but also the processes that have generated them, that being, the reasoning that led to such conclusions and the nature of the decision-making process leading to that alternative. Thus, critical thinking is a higher-order process and, as such, is not automatic, requiring self-determination, reflection, effort, self-control and metacognition. In other words, it is a conscious and deliberate process (Mertes, 1991) involving the interpretation and evaluation of information or experiences.

Critical thinking refers to a type of thinking characterized by its being an alternative to the usual way of thinking; It would be a process that belongs to system 2, in the nomenclature of the theoreticians of the dual process of reasoning (Evans, 2003, 2006; kahneman, 2003). This process does not primarily function on the basis of acquired automatisms, but instead is a reflexive and intended manner of thinking in which individuals activate their cognitive resources (memory, attention) and exert metacognitive control (monitoring and evaluation) over the application of the rules and logical principles that govern reasoning, or over the usual biases that lead to errors in that reasoning (e.g. fallacies). This type of thinking would therefore be an alternative way to the usual process, which operates on the basis of associations between concepts, representations, etc., and that works in parallel, carrying out several operations simultaneously that are activated automatically by stimuli and without will control. This leads the process to become a much faster and less costly route in cognitive terms (De Neys, 2006; Noveck, Mercier, Rossi, \& Van der Henst, 2007). All the foregoing is consistent with the fact that the critical thinking is generally perceived as costly in terms of investments in time, energy, concentration and effort (Valenzuela, Nieto, \& Saiz, 2010).

Most theoreticians working in the field (e.g., Ennis, 1996; Facione, 1990; Halpern, 1998; Paul \& Eldet, 2001) consider that the deployment of this type of thinking depends on 
two components: skills and dispositions. It is unanimously accepted that skills represent the cognitive component (knowing what to do and how to do it) although the taxonomy of the skills comprising critical thinking varies from one researcher to another. In this sense, for example, Ennis (1996) proposes skills such as: focusing on the issue, analyzing arguments, posing and answering clarifying and/or challenging questions, judging the credibility of one's sources, and observing and judging assumptions. Halpern $(1998,2003)$ proposes skills such as: the checking of hypotheses, verbal reasoning, uncertainty and decisions, and the solution of problems and creativity. Swartz \& Perkins (1990) suggest much more general categories: creative thinking, critical thinking, decision-making, the solving of everyday problems and the solving of mathematical problems. This lack of agreement was addressed by an international panel of experts (Facione, 1990) who wished to reach consensus about the concept and meaning of critical thinking. That team identified the following skills as central to critical thinking: interpretation, analysis, assessment, inference, explanation and self-regulation. However, independently of taxonomies, it is deductive and inductive reasoning, problem solving and decision making skills that act as a fundamental structure of critical thinking (Saiz, 2002; Saiz \& Rivas, 2008).

The dispositional component, on the other hand, refers to the extent to which people are disposed to perform a given kind of conduct. However, the term "dispositions" encompasses different conceptualizations (Nieto \& Valenzuela, 2009; Valenzuela \& Nieto, 2009a). Generically, some theoreticians have emphasized the motivational meaning of dispositions, in the sense of considering them as the process that activates skills (e.g., Ennis, 1996; Norris, 1994; Perkins, Jay, \& Tishman, 1993). In contrast, other authors have focused more on dispositions as attitudes or consolidated intellectual habits (e.g., Paul, 1990; Salomon, 1994; Siegel, 1988). Ennis (1996) stated that dispositions are a construct that combines inclinations and attitudes. This second conceptualization is the one best developed and known throughout the work of Facione's team (Facione \& Facione, 1992; Facione, Facione, \& Giancarlo, 2000), who consider them to be characterological or intellectual attributes that include truth-seeking, open-mindedness, analyticity, systematicity, critical thinking self-confidence, inquisitiveness and maturity of judgement. All these would be characteristics associated with a good critical thinker. Nevertheless, empirical studies about the dispositions of critical thinking or the motivational aspects of this way of thinking are few and far between. 
In synthesis, both cognitive and dispositional components seem to be required for critical thinking to be exercised. A person may know which skills to deploy in a given situation, but may not be disposed to do so, such that critical thinking would not be activated. Conversely, a person may be prepared to apply critical thinking skills but may not know how to do so, such that in this case critical thinking would not be activated either. Thus, the activation of both cognitive and dispositional factors will determine critical thinking.

Accordingly, critical thinking is a deliberate process that is not activated automatically and, as such, requires something that will activate it and make subjects persist in their endeavours. As mentioned above, theoreticians have used the dispositions paradigm to refer to the element that activates and maintains this process. However, this theoretical option poses a series of difficulties. More concisely, dispositions appear as a consolidated motivation to think in a critical and rigorous manner; that is, as a habit or an attitude that, as fruit of a series of successful experiences, makes the tendency to address certain problems in life in a critical way. From this perspective, dispositions would be a consistent internal motivation that commits to the solving of problems and making decisions using critical thinking (Facione, Facione, \& Giancarlo, 1996; Facione, et al., 2000). This would be reflected in the extent to which certain characteristics such as truth-seeking, maturity of judgement and openmindedness predispose a person to address certain problems critically (cf. Facione \& Facione, 1992). The problem is that although the authors who hold this perspective highlight the explanatory value of such dispositions in the deployment of critical thinking, they fail to specify: how those dispositional states or intellectual attitudes can be achieved, what the main factors that would lead a person to have a greater or lesser disposition to perform a task are, or the mechanisms through which their modification is possible, with a view to improving performance in critical thinking.

An alternative but complementary perspective is to consider motivation as the central factor of activation and persistence in the cognitive resources necessary for: operating in a critical way, understanding that thinking critically, as a task, depends on the value it is believed to hold, and on the expectation of a successful outcome (cf. Bandura, 1997; Eccles \& Wigfield, 2002). 
Although motivation and dispositions seem to be strongly linked in principle, there are differences between them and the choice of one or another approach has important theoretical and practical repercussions.

The theoretical implications point to the capacity of both approaches to explain how and to what extent dispositions, or motivation, could account for learning and performance in critical thinking tasks. More specifically, which factors might be responsible for each of those tasks (performance and learning) and hence on which factors would it be necessary intervene in order to modify the level of dispositions or motivation.

On the practical side, the dispositions perspective offers an approach that has a solid and valid instrument: the California Critical Thinking Dispositions Inventory (CCTDI), developed by Peter Facione and Colleges (Facione \& Facione, 1992). This inventory allows the level of "intellectual habits or consolidated attitudes" to be evaluated and hence provides a measure of the individuals level on that variable. This measure can be used at a descriptive level in so far that it describes the level a person has in each of the dispositions measured by the test. It can also be used at predictive level. If a person has a good dispositions level, it could be predicted that she or he could be a good critical thinker. In this perspective, we have tested the predictive capacity of the dispositions and the motivation in two measures of critical thinking (PENCRISAL, CCTST). The results showed, independently of critical thinking measure, that the motivation (CTMS) is a more significant variable than the dispositions (CCTDI) and offers a better predictive capacity on critical thinking. On the other hand, the disposition test appears as no significant predictor (Valenzuela \& Nieto, 2009b). Moreover, the test does not explain or provide any indication concerning the acquisition of skills or ways to improve critical thinking. The motivation perspective, at least to date, lacks a solid and valid instrument that is able to provide a measure of that variable. Nevertheless, it does have solid theoretical models to explain the factors involved in the performance and learning of critical thinking. Since we are mainly interested in intervention, that is, the learning of and improvement in the performance of these intellectual skills, we have opted for this second perspective, which together with the theoretical soundness of this approach, gives clues as to how these skills are acquired and improved. But what motivation are we talking about? 


\section{Motivation}

Many approaches have attempted to account for what leads human beings to choose and persist in a task or devote their efforts to a given activity (for a review of the topic, see (Boekaerts, Smelser, \& Baltes, 2001; Carré \& Fenouillet, 2008; Elliot \& Dweck, 2007; Mateos, Palmero, Fernández-Abascal, Martínez, \& Choliz, 2002). Within this plethora of perspectives, several are outstanding for their predictive capacity. For example, the conceptualization of motivation distinguishing intrinsic and extrinsic motivation (Deci, 1976; Deci \& Ryan, 1985, 1999; Sansone \& Harackiewiecz, 2000) has proved to be a theoretical approach which to a large extent allows academic performance to be predicted. However, the weakness in this type of approach is that the range of action remaining for intervention is very limited. If what best predicts performance is having an intrinsic motivation, how can we act on this intentionally? If the motivation is intrinsic, then the most we can hope for is to generate conditions that will favour its emergence. In our view, this is valid for other theoretical options that, despite their virtues, do not provide clearer information as regards to intervention.

Within this context, our theoretical option is inspired in the expectancy/value model proposed by Eccles et al. (1983; Wigfield \& Eccles, 1992; Wigfield \& Eccles, 2000). This model holds that the motivation to perform a particular task would be the product resulting from the expectancy and task value.

The first of these components, Expectancy corresponds to the expectation that a person has about performing a task adequately. This notion is conceptually different from Bandura's $(1977,1986,1997)$ beliefs about self-efficacy, in that the former focuses on future competencies, while Bandura's classic construct focuses on the present. However, in view of the intimate relationship between them (Bandura, Barbaranelli, Caprara, \& Pastorelli, 1996; Eccles, et al., 1983; Eccles \& Wigfield, 1995; Pajares, 1996; Wigfield, Eccles, \& Roeser, 1998) in practice they would be equivalent.

The second component would be the Value assigned to a task. The value of a task would comprise four sub-components: attainment, interest, utility and cost (Eccles et al., 1983; Wigfield \& Eccles, 1992). The attainment value corresponds to how important it is for 
the subject to perform a given task well. This characteristic is closely associated with the person's identity, his or her ideals or his or her ability within a given domain (Wigfield, 1994).

The intrinsic or interest value corresponds to the enjoyment derived from carrying out the task (Wigfield, 1994). This value component draws on the work of Deci \& Ryan (Deci \& Ryan, 1985; Deci, Vallerand, Pelletier, \& Ryan, 1991), who highlight that when the task is valued intrinsically, there are important psychological consequences that have positive repercussions on performance. Stated otherwise, this component of motivation corresponds to the interest aroused (cf. Silvia, 2006). In turn, utility value refers to the extent to which a task fits in with a person's future plans (Wigfield, 1994) and instrumentally evaluates a task as a function of other goals.

Finally, the fourth value component, cost refers to how the decision to commit to an activity limits access to or the possibility of doing other tasks. Thus, this dimension explains how much effort the task will demand and its emotional cost (Wigfield \& Eccles, 2000) (Wigfield \& Eccles, 2000). The proposal of including cost in the "value" construct has been tested empirically by Neuville, Bourgeois, and Frenay (2004), who reported evidence to demonstrate that it belongs to the construct.

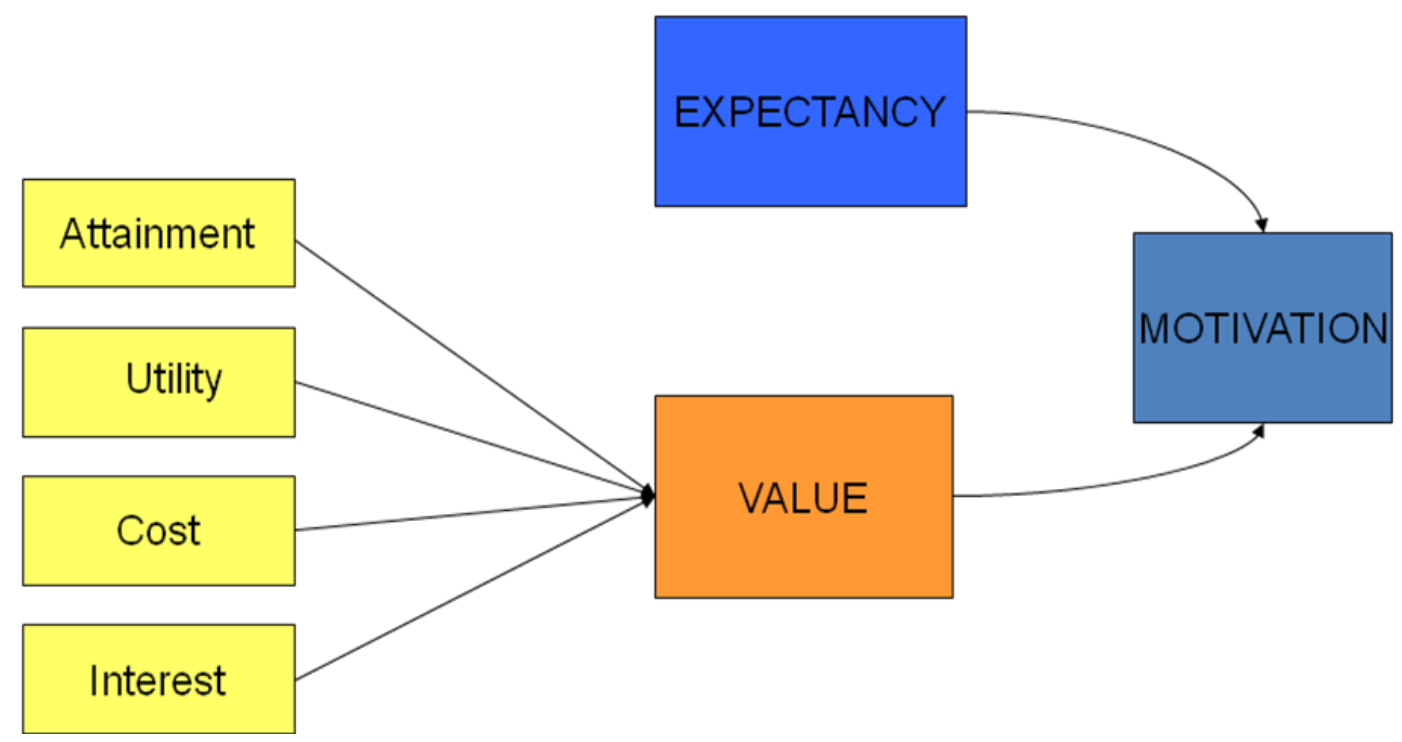

Figure. 1. The motivational model of Eccles and Wigfield (simplified) 
This way of conceiving motivation, inherited from the tradition of Atkinson (1958) or McClelland (1955) developed by Jacqueline Eccles and her team (Eccles et al., 1983; Wigfield, 1994) was conceived as a motivation referring to choice and achievement within a given domain (mathematics). Despite this, we believe that insofar that critical thinking can be thought of as a task, (as a specific form of performing an activity) regardless of the fact that in itself it is not a concrete disciplinary domain, it can be considered as an object of motivation. Accordingly, our object of motivation (expectancy/value) is critical thinking, which is expressed in operative terms as that particular way of thinking characterized by its rigorousness.

\section{Measure instruments}

Like all learning within the context of instruction, as is shown by many studies that have analyzed the motivational effect in learning (see for example, Hattie, 2009; Hattie, Biggs, \& Purdie, 1996; Robbins, et al., 2004), the learning of the skills of critical thinking, or of thinking in general, is influenced by motivational factors. Addressing this issue requires appropriate instruments to explore this, in both the theoretical and practical or psychometric spheres. For this, is important to have a solid and adequate theoretical framework, in this case concerning the level of motivation that a person may have in regard to the task of thinking critically. At the same time, we need an instrument that will allow us to collect valid and reliable information.

There are few instruments that deal with this issue. The only one found is that used by Pintrich and García for their study about the relationship between critical thinking, motivation and learning strategies (Garcia \& Pintrich, 1992). In their work, as a measure of motivation the authors used a scale that measures intrinsic goal orientation; i.e., the degree "to which a student engages in a learning task for reasons such as mastery, challenge, curiosity" (p.7). In other words, we are dealing with a scale that essentially addresses motivation (intrinsic/extrinsic) within the context of learning and whose aim is to establish the relationship between intrinsic motivation to learn and a series of critical habits that would favour learning. The problem involved in studying the motivational factors of critical thinking with an instrument such as this is dual. On one hand, although the theoretical framework within which motivation is conceptualized (intrinsic/extrinsic motivation) does allow predictions to be made, it fails to provide any clues for identifying the main factors that would affect the learning and performance of those skills. On the other hand, it does not put the focus of motivation in par- 
ticular task (learning and using critical thinking) at the forefront, but instead focuses on learning in general.

Our aim, together with gaining insight into the motivational level of students, is to explore which motivational factors might be responsible for such performance, thereby allowing us to intervene in and improve learning. For that, we have constructed a scale that may provide important information about motivation (expectancy/value) with respect to the particular task of thinking critically. Use of a specific instrument such as this would provide us with a particularly useful tool for the study of the motivational factors involved in the acquisition and improvement of these intellectual skills, especially in contexts of formal instruction. This is an important issue in a society that demands increasing improvements in the quality of individual's thinking. Therefore, within this context, the aim of the present study is to validate the Critical Thinking Motivational Scale (CTMS). In this study, we are interested in exploring the psychometric characteristics that endorse the validity and reliability of a scale such as this.

\section{Method}

\section{Participants}

A total of 470 university students students, enrolled in Psychology degree programs from two Spanish universities (Salamanca and Málaga) participated in this validation study. The sample mainly included women $(88.6 \%)$ with a mean age of 21 years $(S D=0.95)$. The subjects participated voluntarily, although a small academic reward was given to them in the subject entitled Psychology of Thinking.

Since the test was not anonymous (the system recognizes the user by identity-ID), the participants were promised the strictest confidentiality concerning their data, which would only be used for research purposes and always reported in aggregate form. 


\section{Instruments}

\section{CTMS- Critical Thinking Motivational Scale}

To be able to study the relationship between motivation and its components and critical thinking, a scale was developed that measures the different components of motivation with respect to critical thinking: namely the Critical Thinking Motivational Scale (CTMS). This scale includes 19 Likert-type items with scores from 1 to 6, concerning which the subjects are requested to express their degree of agreement or disagreement with a series of statements. These statements refer to the expectations each participant has about thinking in a critical or rigorous way (expectancy), and the value (value) of thinking in this manner. The latter including: the importance and usefulness (utility) they perceive in thinking in a rigorous way, the cost they are prepared to accept for thinking in that way, and the interest this way of thinking arouses in them. Although the items are original, they are inspired by other scales (cf. Neuville, et al., 2004). The items of the CTMS, organised in a thematic way, see Table 1.

\section{Table 1. Items of Critical Thinking Motivation Scale (CTMS)}

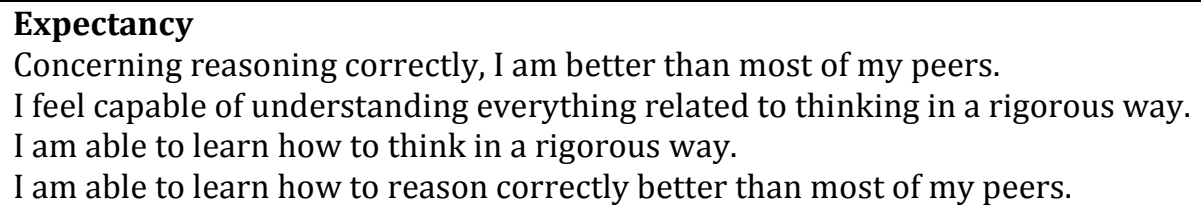

\section{Task value}

Attainment.

For me it is important to learn how to reason correctly.

For me it is important to be good at reasoning.

For me it is important to use my intellectual skills correctly.

For me it is important to be good at solving problems.

Utility value

Thinking critically will help me to become a good professional.

Thinking critically will be useful for my future.

Thinking critically is useful in everyday life.

Thinking critically is useful for other subjects and courses.

Intrinsic/interest value

I like to reason properly before deciding about something.

I like to learn things that will improve my way of thinking.

I like thinking critically.

I like to reason in a rigorous manner.

$\underline{\text { Cost }}$

If I have a problem that requires me to reason in a critical way, I am disposed to sacrifice the time that I would otherwise have devoted to other things.

I am disposed to sacrifice quite a lot of time and effort in order to improve my way of reasoning.

It is worth investing time and efforts to acquire and use critical thinking. 


\section{CT-MSLQ}

As convergent validity measure we used Critical Thinking subscale of the Motivated Strategies for Learning Questionnaire (CT-MSLQ) elaborated by Pintrich, Smith García \& McKeachie (1993), The CT-MSLQ is a five items sub-scale whith a good realibility level $($ alpha $=.77)$ and frecuently used in spanish-speaking contexts (see e.g. Aliaga, Giove, \& Dergan, 2003; Cardozo, 2008; Fernández \& Reinaldo, 2000; Paoloni, 2009)

\section{Procedures}

\section{Preliminary procedures}

The test was first subjected to the consideration of four experts, all with doctorate degrees in psychology, in order to evaluate the validity of its contents and gain some initial feedback in the drafting of the items with regard to possible problems in understanding. The results at this level confirmed the validity of the content and suggested that certain minor modification could be made in the way of expressing two of the items. A total of 37 items were tested in a similar sample by means of an Online Survey Program (Doris) of the Université Catholique de Louvain. This allowed us to refine our selection of items, reducing them to the current number of 19 . To construct the definitive version of the test, the items were randomized so that they would not be grouped thematically.

\section{Test application}

The test was administered collectively. The maximum time allowed to answer the items was 10 minutes. To start the test session, each participant had to access the server by writing his/her log-in (ID number) and a password. During the application of the test, which was supervised by at least one of the investigators, no problems in understanding the items arose.

\section{Analytic procedures}

After the data had been collected, we evaluated the psychometric characteristics of the CTMS. In particular, we explored the following: 
1) The reliability of the test using the Cronbach alpha (Cortina, 1993; Cronbach, 2004; Streiner, 2003) was analyzed to verify the degree of precision with which the CTMS was measuring different constructs.

2) The discriminatory capacity of the test in each of the subscales was examined by means of the discrimination index D proposed by Findley (1956). This corresponds to the differences between the difficulty index of an item (in this case, score 1/5) between the "strong" group $(\mathrm{p}+)$ and the "weak" group (p-); i.e., those formed by individuals situated between the upper and lower $27 \%$ of the scores on the scale (cf. Kelley, 1939).

3) The validity of the construct was considered by contrasting the factorial structure provided by principal component analysis. This was done at the first level, testing the suitability of the items as regards the expectancy and value constructs and, at a second level, as regards the different components of the value construct.

4) Finally, we correlated the CTMS with the critical thinking subscale (CT-MSLQ) of 5 items (alpha $=.77$ ) of the MSLQ (Duncan \& McKeachie, 2005; Pintrich, et al., 1993), according to which, as reported by García and Pintrich (1992), motivation should have a significant degree of association.

\section{Results}

The process of analysis of the psychometric characters of this test comprised 4 parts: reliability, level of discrimination, factorial structure and convergent validity.

\section{Reliability}

Once we had analyzed the validity of the construct by factor analysis, we analyzed the level of precision with which these scales measured each of the constructs. Since the reliability analysis, at least in principle, assumes the unidimensionality of the (sub)scales, we calculated Cronbach alphas for each of them (Cortina, 1993; Streiner, 2003). The results (table 2) revealed a high level of reliability for each of the scales in a range from .732 (expectancy) to .849 (value). 
Table 1. CTMS: Reliability and Discrimination Index

\begin{tabular}{|c|c|}
\hline Utility & $\alpha=.849$ \\
\hline Thinking critically will be useful for my future. & .33 \\
\hline Thinking critically will help me to be a good professional. & .34 \\
\hline Thinking critically is useful for other subjects and courses. & .35 \\
\hline Thinking critically is useful for everyday life. & .36 \\
\hline Interest & $\alpha=.760$ \\
\hline I like to reason in a rigorous way. & .37 \\
\hline I like thinking critically. & .37 \\
\hline I like to reason properly before deciding about something. & .33 \\
\hline I like to learn things that will improve my way of thinking. & .24 \\
\hline Cost & $\alpha=.800$ \\
\hline $\begin{array}{l}\text { I am prepared to sacrifice quite a lot of time and effort in order to improve my } \\
\text { way of reasoning. }\end{array}$ & .39 \\
\hline $\begin{array}{l}\text { If I have a problem that requires reasoning in a critical way I am prepared to } \\
\text { sacrifice time that I would otherwise spend doing other activities. }\end{array}$ & .37 \\
\hline It is worth investing time and efforts to acquire and use critical thinking. & .33 \\
\hline Attainment & $\alpha=.832$ \\
\hline For me it is important to be good at reasoning. & .36 \\
\hline For me it is important to be good at solving problems. & .36 \\
\hline For me it is important to learn how to reason correctly. & .26 \\
\hline For me it is important to use my intellectual skills correctly. & .28 \\
\hline Expectancy & $\alpha=.732$ \\
\hline Concerning reasoning correctly, I am better than most of my peers. & .14 \\
\hline I am able to learn how to reason correctly better than most of my peers. & .13 \\
\hline I feel capable of understanding everything related to thinking in a rigorous way. & .26 \\
\hline I am able to learn how to think in a rigorous way. & .32 \\
\hline
\end{tabular}

\section{Discrimination level of the items}

Bearing in mind that it is sometimes necessary to compare groups, we believe it is also pertinent to report the level of discrimination of the items; that is, the capacity or sensitivity of the items of this test to distinguish the high-motivation group from the low-motivation group (upper and lower 27\% of the scale). The results obtained for the D index (Findley, 1956; Kelley, 1939) were in general very satisfactory (see table 2), most of them being considered fair or good. In particular, we only found two items with a D index lower than .2, qualifying as "limit items" (Ebel, 1965), both of them on the expectancy scale. The other items of the expectancy scale compensate these two items with lower discrimination capacity, with D scores of .26 and .36, giving a mean of .213 for the subscale as a whole. However, we observed in all the subscales a statistically significant difference between upper and lower group (Expectancy: $t=.9763 ; p<.033$, Utility: $t=.9820 ; p<.025$, Attainment: $t=1,000 p<.001$, Cost: $t=$ 
$.9965 ; p<.004$, Interest: $t=.9820 ; p<.014)$. On other hand, all subscales have statistical differences $(p<.001)$ with the top scale value. Therefore, in addition of a good level of discrimination, this scale does not have a ceiling effect.

\section{Factor structure}

To contrast the suitability of the items in regards to the theoretical structure, we performed two factorial analyses. The first (principal components, varimax rotation), which sought to contrast the distinction between expectancy and value, revealed a high degree of adaptation of the data for the factor analysis, Kaiser-Meyer-Olkin index of .868 and a significant Bartlett test $\left(\chi^{2}=4681.108, d f=171, p<.001\right)$. In the factor analysis, the items belonging to the value construct, on one hand, and on the other those corresponding to expectancy were clearly distinguished (see table 3), with a total explanation of the variance of $52.88 \%$.

Table 2. CTMS: Correlation between Variables and Descriptive Statistics

\begin{tabular}{lcccccc} 
& Expectancy & Value & Attainment & Cost & Interest & Utility \\
\hline Expectancy & & & & & & \\
Value & $.360^{* * *}$ & & & & & \\
Attainment & $.227^{* *}$ & $.813^{* *}$ & & & & \\
Cost & $.253^{* *}$ & $.807^{* *}$ & $.533^{* *}$ & & & \\
Interest & $.424^{* *}$ & $.802^{* *}$ & $.559^{* *}$ & $.512^{* *}$ & & \\
Utility & $.261^{* *}$ & $.799^{* *}$ & $.556^{* *}$ & $.501^{* *}$ & $.531^{* *}$ & \\
\hline Mean & 3.7624 & 4.9535 & 5.2343 & 4.5336 & 4.9249 & 5.1213 \\
SD & .04157 & .02951 & .03451 & .04065 & .03549 & .03595
\end{tabular}

A second analysis (maximum likelihood and oblimin rotation, in view of the correlation among the items, see table 4) was performed to determine whether the items corresponding to the value construct were distinguished from one another and were in agreement with the 4-component theoretical proposal of Eccles and Wigfield (2002; Neuville, et al., 2004). In this case, as in the first analysis, we observed a high KMO (.887), and a significant Bartlett test $\left(\chi^{2}=1784,657, d f=105, p<.001\right)$. In this second analysis (see table 5), in agreement with what was foreseen theoretically, it was observed that the items were organized around each of the value components (utility value, attainment, cost and interest) with a total explanation of the variance of $60.693 \%$. 
Table 3. CTMS : Motivation Factorial structure.

\begin{tabular}{lll}
\hline & \multicolumn{2}{c}{ Factor } \\
& 1 & 2 \\
\hline Value & .781 \\
It is worth investing time and efforts to acquire and use critical thinking & .752 \\
For me it is important to be good at reasoning. & .741 \\
Thinking critically will be useful for my future. & .721 \\
For me it is important to learn how to reason correctly. & .700 \\
For me it is important to use my intellectual skills correctly. & .680 \\
Thinking critically will help me to be a good professional. & .639 \\
I am disposed to sacrifice quite a lot of time and effort in order to improve my way & \\
of reasoning. & .615 \\
Thinking critically is useful for other subjects and courses. & .580 \\
Thinking critically is useful for everyday life. & .563 \\
I like thinking critically. & .560 \\
For me it is important to be good at solving problems. & .548 \\
I like to learn things that will improve the quality of my thinking. & .547 \\
I like to reason in a rigorous way. & .330 \\
If I have a problem that requires reasoning in a critical way, I am disposed to sacrifice & .458 \\
time that I would otherwise spend doing other activities. & \\
I like to reason properly before deciding about something. & .328 \\
& \\
Expectancy & \\
Concerning reasoning correctly, I am better than most of my peers. & \\
I am able to learn how to reason correctly better than most of my peers. & .804 \\
I feel capable of understanding everything related to thinking in a rigorous way. & .803 \\
I am able to learn how to think in a rigorous way. & .633 \\
\hline Eigenvalue & .624 \\
\% of Variance & 34.137 & 10.444 \\
\hline
\end{tabular}

Extraction Method: principal components. Rotation Method: Varimax with Kaiser Normalization.

Rotation converged in 3 iterations. For a better legibility, the scores smaller to .3 are omitted. 
Table 4. CTMS: Value Construct Factorial Structure

\begin{tabular}{|c|c|c|c|c|}
\hline & \multicolumn{4}{|c|}{ Factor } \\
\hline & 1 & 2 & 3 & 4 \\
\hline \multicolumn{5}{|l|}{ Utility } \\
\hline Thinking critically will be useful for my future. & .811 & & & \\
\hline Thinking critically will help me to be a good professional. & .824 & & & \\
\hline Thinking critically is useful for other subjects and courses. & .655 & & & \\
\hline Thinking critically is useful for everyday life. & .667 & & & \\
\hline \multicolumn{5}{|l|}{ Cost } \\
\hline $\begin{array}{l}\text { I am disposed to sacrifice quite a lot of time and effort in order to } \\
\text { improve my way of reasoning. }\end{array}$ & & .807 & & \\
\hline $\begin{array}{l}\text { If I have a problem that requires reasoning in a critical way, I am } \\
\text { disposed to sacrifice time that I would otherwise spend doing other } \\
\text { activities. }\end{array}$ & & .430 & & \\
\hline $\begin{array}{l}\text { It is worth investing time and efforts to acquire and use critical think- } \\
\text { ing. }\end{array}$ & & .905 & & \\
\hline \multicolumn{5}{|l|}{ Attainment } \\
\hline For me it is important to be good at reasoning correctly. & & & -.692 & \\
\hline For me it is important to be good at solving problems. & & & -.885 & \\
\hline For me it is important to learn how to reason correctly. & & & -.649 & \\
\hline For me it is important to use my intellectual skills correctly. & & & -.564 & \\
\hline \multicolumn{5}{|l|}{ Interest } \\
\hline I like to learn things that will improve my way of thinking. & & & & .902 \\
\hline I like to reason in a rigorous way. & & & & 630 \\
\hline I like thinking critically. & & & & .587 \\
\hline I like to reason properly before deciding about something. & & & & .366 \\
\hline Eigenvalue & 6.05 & 1.22 & 1.10 & 1.06 \\
\hline$\%$ of Variance & 40.3 & 8.1 & 7.3 & 7.1 \\
\hline
\end{tabular}

\section{Convergent Validity}

Finally, we evaluated the convergent validity of the scale by analyzing the degree of correlation between the CTMS and the critical thinking subscale (CT-MSLQ) of the Motivated Strategies for Learning Questionnaire (Pintrich, et al., 1993). The research reported by García and Pintrich (1992) had already shown that there is a significant correlation $(r=.50-$ $r=.57$ ) between motivation and critical thinking, in this case conceptualized as critical habits oriented towards learning. This association should also be significant with the CTMS since, although based on another theoretical framework, it also measures motivation.

The results (see table 6) reveal that both expectancy and value have a significant association with the CT-MSLQ $(p<.001)$. Likewise, the elements comprising the value construct also show a significant correlation $(p<.001)$ between motivation and critical thinking. Thus, the data collected shows that, similar to the Intrinsic Global Orientation Scale (Garcia \& 
Pintrich, 1992), the CTMS reveals not only a significant association with this variable but also does so to a fairly similar degree.

Table 5. Correlations between Critical Thinking (CT-MSLQ) and Motivation (CTMS)

\begin{tabular}{lccccccc}
$\begin{array}{l}\text { Critical Thin- } \\
\text { king } \\
\text { SMLQ }\end{array}$ & $\begin{array}{c}\text { Motivation } \\
(\text { E x V) }\end{array}$ & Expectancy & Value & $\begin{array}{c}\text { Attain- } \\
\text { ment }\end{array}$ & Cost & Interest & Utility \\
\hline $\begin{array}{l}\text { Pearson corre- } \\
\text { lation }\end{array}$ & $.522^{* *}$ & $.504^{* *}$ & $.486^{* *}$ & $.351^{* *}$ & $.440^{* *}$ & $.497^{* *}$ & $.342^{* *}$ \\
Sig. (2-tailed) & .000 & .000 & .000 & .000 & .000 & .000 & .000 \\
$\mathrm{~N}$ & 455 & 458 & 456 & 461 & 460 & 459 & 462 \\
\hline
\end{tabular}

** Correlation is significant at the .01 level (2-tailed).

\section{Discussion and Conclusions}

In this work, we have shown that it is appropriate to address the problem of the activation of cognitive resources to learn and perform critical thinking skills from the theoretical framework of motivation. We have shown the benefits of this theoretical model over the dispositions model in the sense that its advantages derive from the theoretical capacity to explain how such processes are activated and acquired. Additionally, we have shown the suitability of a solid theoretical model that will reveal concrete elements whose possible modification may contribute to a better learning and performance of critical thinking skills.

In this sense, the construction of an instrument that measures motivation to think in an analytic and rigorous way, based on the expectancy/value model (Eccles \& Wigfield, 2002), provides important clues for the study of the motivational determinants that affect the acquisition and performance of such skills.

The resulting test was validated in a sample of university students. The results show a concordant factorial structure with the theoretical proposal of Eccles \& Wigfield, both in regard to expectancy/value distinction and the distinction between the different components forming the value construct. Also, on each of the subscales, the CTMS shows a high capacity for precision in the measurement of those constructs (alphas $=.732$ to .849 ). Another psychometric characteristic that supports the soundness of this scale is the level of discrimination of its items, with a mean D index of .31. Finally, the results of the correlation of the CTMS 
scale with critical thinking skills, measured through the critical thinking subscale of the CTMSLQ (García \& Pintrich, 1992), are similar to those obtained by the motivational scale used by García and Pintrich, conceived under the perspective of intrinsic/extrinsic motivation (Deci, 1976; Deci and Ryan, 1985).

It is important to note that the correlations found between critical thinking skills and motivation, evaluated both with the CTMS and the MSLQ, afford much higher values (around .50) than those obtained between critical thinking skills and dispositions (Facione, et al., 2000 ), with values around $r=.201$. This greater association between skills and motivation suggests that the motivational perspective could have greater explanatory power regarding performance in critical thinking than the dispositions perspective. Nevertheless, it would be necessary to carry out a specific study attempting to clarify and specifically compare the explanatory and predictive power of both constructs: disposition and motivation. Moreover, the scale that we propose for the measurement of motivation towards critical thinking is based on a solid model of motivation (e.g. Eccles et al. 1983; Wigfield, 1994; Wigfield \& Eccles, 1992, 2000) with some clearly specified components. This would allow to us to know and intervene in the components with good indices of prediction in the performance and learning of the critical thinking.

This approach will not only allow us to determine the motivational level of a person, but also to know the value for that person of a task requiring critical thinking and that person's expectancy about that task. Accordingly, the motivation approach would provide greater flexibility and greater indications for intervening in the motivational component of critical thinking when this shows deficient levels. Thus, the motivational option could have greater advantages not only at empirical level, which as seen could better account for the performance of thinking, but also at instructional level, providing clues about which variables should be tackled to foster critical thinking.

Although the results are positive, this study is limited, in that the sample constitutes primarily women $(88.6 \%)$. A complementary study would have to contemplate a greater masculine sample to state possible genre differences, and others specifics populations. Future works would need to verify if these psychometrics traits are valid for the translations version, and also consider the possibility of comparing groups theoretically expected to differ on motivation for critical thinking (e.g. philosophy professor v/s accountants). 
In summary, we have observed that the CTMS, with the indicated limitations, has psychometric characteristics that support its appropriateness as a useful instrument in research addressing the acquisition and performance of critical thinking skills and that owing to its theoretical basis it may provide clues to potential pedagogical interventions.

\section{Acknowledgments}

This project was supported by a Santander Group Research Scholarship to first author.

\section{References}

Aliaga, J., Giove, A., \& Dergan, J. (2003). Adaptación y caracterìsticas psicométricas del $M S L Q$. Paper presented at the XXIX Congreso Interamericano de Psicología, Lima.

Atkinson, J. W. (1958). Towards experimental analysis of human motivation in terms of motives, expectancies, and incentives. Motives in fantasy, action and society, 288305.

Bandura, A. (1977). Self-efficacy: Toward a unifying theory of behavioral change. Psychological Review, 84(2), 191-215.

Bandura, A. (1986). Social foundations of thought and action. New York: Prentice-Hall.

Bandura, A. (1997). Self-Efficacy: The Exercise of control. New York: W.H. Freeman and Company.

Bandura, A., Barbaranelli, C., Caprara, G., \& Pastorelli, C. (1996). Multifaceted impact of self-efficacy beliefs on academic functioning. Child Development, 67(3), 1206-1222.

Boekaerts, M., Smelser, N. J., \& Baltes, P. B. (2001). Motivation, Learning, and Instruction. In N.J.Smelser \& P. B. Baltes (Eds.), International Encyclopedia of the Social and Behavioral Sciences (pp. 10112-10117). Oxford: Elsevier.

Cardozo, A. (2008). Motivación y rendimiento académico en estudiantes del primer año universitario. Revista de Educación, 14(28).

Carré, P., \& Fenouillet, F. (Eds.). (2008). Traité de psychologie de la motivation - Théorie et Pratiques. Paris: Dunod. 
Cortina, J. M. (1993). What is coefficient alpha? An examination of theory and applications. Journal of Applied Psychology, 78, 98-104.

Cronbach, L. J. (2004). My Current Thoughts on Coefficient Alpha and Successor Procedures. Los Angeles, CA: Center for the Study of Evaluation (CSE)National Center for Research on Evaluation, Standards, and Student Testing (CRESST)Graduate School of Education \& Information Studies.

De Neys, W. (2006). Automatic-heuristic and executive-analytic processing during reasoning: Chronometric and dual-task considerations. Quarterly Journal of Experimental Psychology, 59(6), 1070-1100.

Deci, E. L. (1976). Intrinsic motivation. New York: Plenum Press.

Deci, E. L., \& Ryan, R. M. (1985). Intrinsic motivation and self-determination in human behavior. New York: Plenum.

Deci, E. L., \& Ryan, R. M. (1999). A Meta-Analytic Review of Experiments Examining the Effects of Extrinsic Rewards on Intrinsic Motivation. Psychological Bulletin, 125(6), 627-668.

Deci, E. L., Vallerand, R. J., Pelletier, L. G., \& Ryan, R. M. (1991). Motivation and Education: The Self-Determination Perspective. Educational Psychologist, 26(3/4), 325-346.

Duncan, T. G., \& McKeachie, W. J. (2005). The making of the motivated strategies for learning questionnaire. Educational Psychologist, 40(2), 117-128.

Ebel, R. L. (1965). Measuring educational achievement: Prentice-hall.

Eccles, J., Adler, T. F., Futterman, R., Goff, S. B., Kaczala, C. M., Meece, J. L., et al. (1983). Expectancies, values, and academic behaviors Achievement and achievement motivation (pp. 75-146). San Francisco, CA: W.H.Freeman.

Eccles, J., \& Wigfield, A. (1995). In the mind of the actor: The structure of adolescents' achievement task values and expectancy-related beliefs. Personality and Social Psychology Bulletin, 3(21), 215-225.

Eccles, J., \& Wigfield, A. (2002). Motivational beliefs, Values and Goals. In S. T. Fiske, D. L. Schacter \& C. Sahn-Waxler (Eds.), Annual Review of Psychology (pp. 109-132). Palo Alto, CA: Annual Reviews.

Elliot, A. J., \& Dweck, C. S. (2007). Handbook of Competence and Motivation. London: The Guilford Press.

Ennis, R. H. (1996). Critical Thinking. Upper Saddle River, New Jersey: Prentice-Hall. 
Evans, J. S. B. T. (2003). In two minds: dual process accounts of reasoning. Trends in Cognitive Sciences, 7(10), 454-459.

Evans, J. S. B. T. (2006). The heuristic-analytic theory of reasoning: Extension and evaluation. Psychonomic Bulletin \& Review 13(3), 378-395.

Facione, P. A. (1990). APA Delphi Research Report, Critical Thinking: A Statement of Expert Consensus for Purposes of Educational Assessment and Instruction. ERIC Doc.No.: ED, 315, 423.

Facione, P. A., \& Facione, N. C. (1992). The California Critical Thinking Dispositions Inventory (CCTDI); and the CCTDI Test Manual. Millbrae, CA: The California Academic Press.

Facione, P. A., Facione, N. C., \& Giancarlo, C. A. F. (1996). The motivation to think in working and learning. New Directions for Higher Education, 1996(96), 67-79.

Facione, P. A., Facione, N. C., \& Giancarlo, C. A. F. (2000). The disposition toward critical thinking: Its character, measurement, and relationship to critical thinking skill. Informal Logic, 20(1), 61-84.

Fernández, M., \& Reinaldo, J. (2000). Motivación, estrategias de aprendizaje y evaluación del rendimiento en alumnos universitarios. Iberpsicologİa: Revista Electrónica de la Federación española de Asociaciones de Psicologİa, 5(2), 2.

Findley, W. G. (1956). A rationale for evaluation of item discrimination statistics. Educational and Psychological Measurement, 16, 175-180.

Garcia, T., \& Pintrich, P. R. (1992). Critical Thinking and Its Relationship to Motivation, Learning Strategies, and Classroom Experience. Paper presented at the Annual Meeting of the American Psychological Association. Washington, DC.

Halpern, D. (1998). Teaching Critical Thinking for Transfer Across Domains: Dispositions, Skills, Structure Training, and Metacognitive Monitoring. American Psychologist, 53(4), 449-455.

Halpern, D. (2003). Halpern Critical thinking Assessment: Background and scoring standards.Unpublished manuscript.

Hattie, J. (2009). Visible learning: A synthesis of 800+ meta-analyses on achievement: Oxford: Routledge.

Hattie, J., Biggs, J., \& Purdie, N. (1996). Effects of Learning Skills Interventions on Student Learning: A Meta-Analysis. Review of Educational Research, 66(2), 99-136.

kahneman, D. (2003). A perspective on judgment and choice. Mapping bounded rationality. American Psychologist 58(9), 697-720. 
Kelley, T. L. (1939). Selection of upper and lower groups for the validation of test items. Journal of Educational Psychology, 30, 17-24.

Leveault, D., \& Grégoire, J. (2002). Introduction aux théories des tests. Bruxelles: De Boeck.

Mateos, M., Palmero, F., Fernández-Abascal, E., Martínez, F., \& Choliz, M. (2002). Teorías Motivacionales Psicología de la de la Motivación y la Emoción (pp. 155-186). Madrid: Mc Graw Hill.

Mc Clelland, D. C. (1955). Studies in Motivation. New York: Appleton Century Croft.

Mertes, L. (1991). Thinking and Writing. Middle School Journal, 22, 24-25.

Neuville, S., Bourgeois, É., \& Frenay, M. (2004). The subjective task value: clarification of a construct. In S. Neuville (Ed.), La perception de la valeur des activités d'apprentissage : étude des déterminants et effets. Louvain la neuve: Unpublished Doctoral Thesis. Université Catholique de Louvain.

Nieto, A., \& Valenzuela, J. (2009). Estudio de la estructura interna de las disposiciones del pensamiento crítico. [Submited article].

Norris, S. P. (1994). The meaning of critical thinking test performance: The effects of abilities and dispositions on scores. Critical thinking: Current research, theory, and practice. Dordrecht, The Netherlands: Kluwer.

Noveck, I., Mercier, H., Rossi, S., \& Van der Henst, J. B. (2007). Psichologie cognitive du raisonnement. In S. Rossi \& J. B. Van der Henst (Eds.), Psychologies $d u$ raisonnement. Bruxelles: de Boeck.

Pajares, F. (1996). Self-Efficacy beliefs in Academic Settings. Review of Educational Research, 66(4), 543-578.

Paoloni, P. V. (2009). Contextos favorecedores de la motivación y el aprendizaje. Una propuesta innovadora para alumnos de Ingeniería. Electronic Journal of Research in Educational Psychology, 7(19), 953-984.

Paul, R. (1990). Critical Thinking: What every person need to survivre in a rapidly changing word. Rohnert Park, CA: Center for Critical Thinking and Moral Critique, Sonoma State University.

Paul, R., \& Eldet, L. (2001). Critical thinking: Tools for taking charge of your learning and your life. Upper Saddle River, New Jersey Prentice Hall.

Perkins, D. N., Jay, E., \& Tishman, S. (1993). Beyond Abilities: A Dispositional Theory of Thinking. Merrilll Palmer Quaterly 39, 1-1. 
Pintrich, P. R., Smith, D. A. F., Garcia, T., \& McKeachie, W. J. (1993). Reliability and predictive validity of the Motivated Strategies for Learning Questionnaire (MSLQ). Educational and psychological measurement, 53(3), 801.

Robbins, S., Lauver, K., Le, H., Davis, D., Langley, R., \& Carlstrom, A. (2004). Do psychosocial and study skill factors predict college outcomes? A meta-analysis. Psychological Bulletin, 130(2), 261-288.

Saiz, C. (Ed.). (2002). Pensamiento crítico: conceptos básicos y actividades prácticas. Madrid: Pirámide.

Saiz, C., \& Rivas, S. (2008). Intervenir para transferir en Pensamiento Crítico. Revista Praxis, 10(13), 129-149.

Salomon, G. (1994). To be or not to be (mindful). Paper presented at the Annual Meeting of the American Educational Research Association.

Sansone, C., \& Harackiewiecz, J. (2000). Intrinsic and Extrinsic motivation: the search for optimal motivation and performance. San Diego: Academic Press.

Siegel, H. (1988). Educating reason: Rationality, critical thinking, and education: Routledge.

Silvia, P. J. (2006). Exploring the Psychology of Interest. Oxford: Oxford Uiversity Press.

Streiner, D. L. (2003). Starting at the Beginning: An Introduction to Coefficient Alpha and Internal Consistency. Journal of Personality Assessment, 80(1), 99-103.

Swartz, R. J., \& Perkins, D. N. (1990). Teaching thinking: Issues and approaches. Pacific Grove, CA: Critical Thinking Press \& Software.

Valenzuela, J., \& Nieto, A. (2009a). Estudio de la estructura interna de las disposiciones del pensamiento crítico. Paper presented at the VI Simposio de la Asociación de Motivación y Emoción (AME). Tenerife, Spain.

Valenzuela, J., \& Nieto, A. (2009b, may, 6-0). Motivación y Disposiciones como predictores del desempeño del Pensamiento Crítico. Paper presented at the VI Simposio de la Asociación de Motivación y Emoción (AME). Tenerife, Spain.

Valenzuela, J., Nieto, A., \& Saiz, C. (2010). Percepción del coste de utilización Pensamiento crítico en universitarios chilenos y españoles. Electronic Journal of Research in Educational Psychology 8(2), 689-706.

Wigfield, A. (1994). Expectancy-value theory of achievement motivation: A developmental perspective. Educational Psychology Review, 6(1), 49-78.

Wigfield, A., \& Eccles, J. (1992). The development of achievement task values: A theoretical analysis. Developmental Review, 12, 265-310. 
Wigfield, A., \& Eccles, J. (2000). Expectancy-Value Theory of Achievement Motivation. Contemporary educational psychology, 25(1), 68-81.

Wigfield, A., Eccles, J., \& Roeser, R. (1998). Relations of young children's ability related beliefs to their subjective task values, performance, and effort. Paper presented at the "Motivation and affect in the classroom" (P. Pintrich, Organizer) at the International Congress of Applied Psychology. 